\title{
ASSESSMENT OF THE GLYCEMIC INDEX OF GROATS AVAILABLE ON THE POLISH FOOD MARKET
}

\author{
Dorota Różańska ${ }^{1}$ Katarzyna Mikośz ${ }^{2}$ Bożena Regulska-Ilow ${ }^{l}$
}

${ }^{1}$ Department of Dietetics, Wroclaw Medical University, Wrocław, Poland

${ }^{2}$ Students Scientific Club at the Department of Dietetics, Wroclaw Medical University, Wrocław, Poland

\begin{abstract}
Background: Glycemic index (GI) and glycemic load (GL) are often used to assess diet quality in relation to the risk of diabetes, cardiovascular diseases and cancer development. Taking into account differences in nutritional value of food products in different countries it is often suggested to used national databases to assess dietary intake in different populations. Objective: To assess the glycemic index and glycemic load of the selected groats available on the Polish food market.

Material and methods: GI of the following groats available on the Polish food market was assessed: couscous, buckwheat (roasted) groats, millet groats, spelt groats, barley (hulled) groats and bulgur groats. The GI was assessed as the incremental area under the blood glucose response curve of a $50 \mathrm{~g}$ carbohydrate portion of a test food expressed as a percent of the response to the same amount of carbohydrate from a standard food taken by the same subject. GL was calculated for the $100 \mathrm{~g}$ of the cooked product.

Results: The lowest GI was found for buckwheat (34.7 $\pm 8.2 \%)$ and barley $(31.3 \pm 13.4 \%)$ groats. The GL for these groats was $8.1 \pm 1.9$ and $8.0 \pm 3.4$, respectively. The GI for millet, spelt and bulgur groats amounted to $56.2 \pm 20.6 \%, 69.8 \pm 35.0 \%$, $64.5 \pm 36.8 \%$, respectively, while for couscous amounted to $99.0 \pm 36.0 \%$. The highest GL was observed for couscous (24.7 \pm 9.0$)$.

Conclusions: The groats tested in this study can be classified as follows: barley and buckwheat as a low GI food, millet and bulgur as a medium GI food, spelt and couscous as a high GI food. Buckwheat and barley groats should be chosen the most often among these products, while the intake of couscous should be limited especially by people with diabetes.
\end{abstract}

Key words: glycemic index; groats; carbohydrates; area under the curve; glycemic load; glucose

\section{STRESZCZENIE}

Wprowadzenie: Indeks glikemiczny i ładunek glikemiczny są często wykorzystywane do oceny jakości diety w odniesieniu do ryzyka rozwoju cukrzycy, chorób sercowo-naczyniowych i nowotworów. Biorąc pod uwagę różnice w wartości odżywczej produktów spożywczych w różnych krajach, często zaleca się stosowanie krajowych baz danych w celu oceny sposobu żywienia w różnych populacjach.

Cel badań: Ocena indeksu glikemicznego (IG) i ładunku glikemicznego (ŁG) wybranych kasz dostępnych na polskim rynku spożywczym.

Material i metody: Oceniono IG następujących kasz dostępnych na polskim rynku spożywczym: kuskus, kasza gryczana (prażona), kasza jaglana, kasza orkiszowa, kasza jęczmienna (pęczak) i kasza bulgur. Wartość IG obliczono jako stosunek pola powierzchni pod krzywą glikemiczną po spożyciu produktu zawierającego $50 \mathrm{~g}$ węglowodanów w badanej żywności do pola powierzchni pod krzywą glikemiczną po spożyciu $50 \mathrm{~g}$ glukozy u tej samej osoby. ŁG obliczono dla 100 g gotowanego produktu. Wyniki: Najniższy IG stwierdzono dla kaszy gryczanej $(34,7 \pm 8,2 \%)$ i jęczmiennej $(31,3 \pm 13,4 \%)$. Wartość ŁG dla tych kasz wynosiła odpowiednio 8,1 $\pm 1,9$ i 8,0 03,4 . Wartość IG dla kaszy jaglanej, orkiszowej i bulgur wynosiła odpowiednio $56,2 \pm 20,6 \%$, $69,8 \pm 35,0 \%, 64,5 \pm 36,8 \%$, natomiast dla kaszy kuskus 99,0 $036,0 \%$. Najwyższy ŁG stwierdzono dla kaszy kuskus $(24,7 \pm 9,0)$.

Wnioski: Analizowane kasze można sklasyfikować następująco: jęczmienną i gryczaną jako produkty o niskim IG, jaglaną i bulgur jako produkty o średnim IG, orkiszową i kuskus jako produkty o wysokim IG. Spośród analizowanych produktów kasza gryczana i jęczmienna powinny być wybierane najczęściej, podczas gdy spożycie kaszy kuskus powinno być ograniczone, szczególnie przez osoby z cukrzycą.

Słowa kluczowe: indeks glikemiczny; kasza; węglowodany; pole powierzchni pod krzywa; ładunek glikemiczny; glukoza

Corresponding author: Dorota Różańska, Department of Dietetics, Wroclaw Medical University, Parkowa 34, 51-616 Wroclaw, Poland, e-mail: dorota.rozanska@umed.wroc.pl

*) This research was conducted as a part of the Project No. ST.E110.16.062, founded by the Wroclaw Medical University (Poland).

(C) Copyright by the National Institute of Public Health - National Institute of Hygiene 


\section{INTRODUCTION}

The glycemic index (GI) is a value used to classified food products in regard to its influence on blood glucose level in relation to the reference product (glucose or white bread). Food can be divided as a low GI $(\leq 55 \%)$, medium GI $(56-69 \%)$ or high GI $(\geq 70 \%)[2,5]$. The concept for GI was published first time in 1981 [5]. Glycemic index is a constant value for each food and do not include the amount of carbohydrates in the portion of the consumed food. The value that joins this two parameters: GI and the amount of carbohydrates in the portion of the consumed food is glycemic load (GL) $[1,2]$.

GI and GL are often used to assess diet quality in relation to the risk of diabetes, cardiovascular diseases and cancer. The meta-analysis conducted by Dong et al. [10] gave the evidence about significant association between dietary GI and GL in the risk of type 2 diabetes. In the EPIC-MORGEN study in the group of men higher dietary GL was associated with an increased risk of coronary heart disease (CHD) and GI was associated with increased risk of stroke in men [6]. Other authors based on the meta-analysis proved that higher dietary GL was associated with the risk of CHD and stroke in women [11]. There are also many studies which shown the positive correlation between dietary GI and/or GL and the risk of cancer, for example colorectal [18], bladder [3], endometrial [22], and breast [19].

Taking into account differences in nutritional value of food products in different countries it is often suggested to used national databases to assess dietary intake in different populations. International Tables of Glycemic Index and Glycemic Load have been published [1,13], however it should be more adequate to use GI and GL values assessed for the typical national products. There is no Polish database with GI and there are only few studies were GI of typical Polish food were assessed [4, 8, 9, 16]. This study was conducted to assess the GI and GL of the selected groats available on the Polish food market.

The aim of the study was to assess the glycemic index and glycemic load of the selected groats available on the Polish food market.

\section{MATERIAL AND METHODS}

\section{Groats preparation}

We used six following groats available on the Polish food market: couscous, buckwheat (roasted) groats, millet groats, spelt groats, barley (hulled) groats and bulgur groats. The nutritional value from the labels of the analyzed groats is presented in Table 1.
The content of digestible carbohydrates was computed as a difference between total carbohydrates and dietary fiber content in each groats. To the analysis we used a portion of each groats that contained $50 \mathrm{~g}$ of available carbohydrates (Table 2). Each groats was weighted and prepared with cooking instruction attached on the package. Time of cooking of each product is shown in Table 2. Groats were prepared just before the consumption.

\section{Glycemic index assessment}

The GI is defined as the incremental area under the blood glucose response curve of a $50 \mathrm{~g}$ carbohydrate portion of a test food expressed as a percent of the response to the same amount of carbohydrate from a standard food taken by the same subject.

The area under the curve has been calculated as the incremental area under the blood glucose response curve (IAUC), ignoring the area beneath the fasting concentration. In the calculation we applied the trapezoid rule. When a blood glucose value falls below the baseline, only the area above the fasting level was included $[5,12]$.

The first stage of the study was to measure the area under the curve (AUC) after the consumption of the standard food (50 g of glucose in $200 \mathrm{~mL}$ of water). First of all we measured fasting blood glucose and then after 15, 30, 45, 60, 90 and 120 minutes after glucose intake. Then the AUC was calculated according to the trapezoid rule. The results of each of the 7 measurements were plotted on the coordinate axes, where OX was glucose level [mg/dL] and OY was time $(0,15,30,45,60,90$ and 120 minutes). Next, the AUC was divided into triangles and trapezoids. The AUC was equals the sum of the areas of the triangles and trapezoids. Negative values of areas of particular figures (when a blood glucose value falls below the baseline) were not included in the calculations [12].

In the second stage, after at least one day break but not more than 7 days, we measured the AUC after the consumption of the tested food containing $50 \mathrm{~g}$ of available carbohydrates. First of all we measured fasting blood glucose and then after 15, 30, 45, 60, 90 and 120 minutes after the food intake. Then the AUC was calculated as it was described above. The volunteers were instructed to eat the grains in the time not exceeded 10 minutes.

According to the FAO/WHO recommendations [12] a capillary blood was used to assess GI. Capillary blood was taken using an automatic disposable lancing device and blood glucose level was measured using a Bayer Contour TS glucometer. 
Table 1. The nutritional value of the analyzed groats (per $100 \mathrm{~g}$ )

\begin{tabular}{|l|c|c|c|c|c|c|}
\hline \multicolumn{1}{|c|}{ Groats } & $\begin{array}{c}\text { Energy } \\
(\mathrm{kcal})\end{array}$ & $\begin{array}{c}\text { Protein } \\
(\mathrm{g})\end{array}$ & $\begin{array}{c}\text { Carbohydrates } \\
(\mathrm{g})\end{array}$ & $\begin{array}{c}\text { Fats } \\
(\mathrm{g})\end{array}$ & $\begin{array}{c}\text { Dietary fiber } \\
(\mathrm{g})\end{array}$ & $\begin{array}{c}\text { Digestible } \\
\text { carbohydrates }(\mathrm{g})\end{array}$ \\
\hline Couscous & 344 & 12.0 & 68.0 & 1.8 & 4.0 & 64.0 \\
\hline Millet & 348 & 10.5 & 68.4 & 2.9 & 3.2 & 65.2 \\
\hline Spelt & 339 & 11.0 & 63.0 & 2.6 & 9.6 & 53.4 \\
\hline Bulgur & 330 & 13.0 & 62.0 & 1.5 & 8.0 & 54.0 \\
\hline $\begin{array}{l}\text { Buckwheat, } \\
\text { roasted }\end{array}$ & 358 & 11.2 & 68.3 & 3.2 & 5.8 & 62.5 \\
\hline Barley, hulled & 362 & 8.4 & 74.9 & 2.0 & 5.4 & 69.5 \\
\hline
\end{tabular}

Table 2. Methods of preparation of each groats

\begin{tabular}{|l|c|l|c|}
\hline \multicolumn{1}{|c|}{ Groats } & \multicolumn{1}{|c|}{$\begin{array}{c}\text { Portion of raw product } \\
\text { containing 50 g of available } \\
\text { carbohydrates }(\mathrm{g})\end{array}$} & \multicolumn{1}{c|}{$\begin{array}{c}\text { Preparation } \\
\text { after cooking (g) }\end{array}$} \\
\hline Couscous & 78 & $\begin{array}{l}\text { pour with boiling water, cover and set } \\
\text { aside for 3 minutes }\end{array}$ & $201.0 \pm 9.2$ \\
\hline Millet & 77 & $\begin{array}{l}\text { boiled for about 15 minutes until all } \\
\text { the water has been absorbed }\end{array}$ & $223.0 \pm 2.6$ \\
\hline Spelt & 94 & boiled for 13 minutes & $272.3 \pm 1.2$ \\
\hline Bulgur & 92 & $\begin{array}{l}\text { boiled for 15 minutes until all the } \\
\text { water has been absorbed }\end{array}$ & $265.0 \pm 2.6$ \\
\hline Buckwheat, roasted & 80 & boiled for 13 minutes & $213.3 \pm 5.5$ \\
\hline Barley, hulled & 72 & boiled for 15 minutes & $195.7 \pm 2.5$ \\
\hline
\end{tabular}

Each food was tested in 8 volunteers. Volunteers have to be after 12 hours of night fasting and meet the inclusion criteria described below in section "volunteers". During the study volunteers could not consume any other food products, chew gum or drink flavored/sweetened beverages. They were instructed to sit and not to walk during the study.

Glycemic index for each groats was the average value of 8 results obtained in different volunteers.

\section{Volunteers}

The volunteers were adults who signed an informed consent for participation in the study. The inclusion criteria were:

- age $\geq 18$ years old

- without diabetes or insulin resistance in the history

- no pharmacotherapy

- fasting for 12 hours before the study

The study group included 44 individuals (35 women, 9 men). Four volunteers agreed to take part in the study for two products within one week. The mean age of the volunteers was $23.7 \pm 5.8$ years old.

The study was approved by the Polish Ethics Committee (No. KB-342/2016).

\section{Glycemic load assessment}

Glycemic load was computed according to the formula:

$\mathrm{GL}=(\mathrm{GI} x$ carbohydrate content in the portion $) / 100$

GL was calculated for the $100 \mathrm{~g}$ of the cooked product. GI value for each groats was the average value of 8 measurements obtained in different volunteers.

\section{RESULTS}

Table 3 shows the mean value of blood glucose level $[\mathrm{mg} / \mathrm{dL}]$ after the intake of $50 \mathrm{~g}$ of glucose or the portion of product contains $50 \mathrm{~g}$ of digestible carbohydrates. The highest blood glucose level after the intake of glucose was observed in the $30^{\text {th }}$ minute of the study. The glycemic curve for couscous groats has reached its maximum in the $30^{\text {th }}$ minute but was almost unchanged until $45^{\text {th }}$ minute. The glycemic curve for millet, buckwheat and barley groats have also reached the maximum in the $30^{\text {th }}$ minute of the study. The glycemic curve for spelt groats has reached its maximum in the $15^{\text {th }}$ minute, while for bulgur groats in $60^{\text {th }}$ minute.

Figure 1 shows the glycemic curves for each groats and the reference glycemic curve for glucose. 
Table 3. The mean value of blood glucose level $[\mathrm{mg} / \mathrm{dL}]$ after the intake of reference or tested product

\begin{tabular}{|c|c|c|c|c|c|c|c|c|}
\hline \multirow{2}{*}{\multicolumn{2}{|c|}{ Glucose or groats }} & \multicolumn{7}{|c|}{ Blood glucose level [mg/dL] } \\
\hline & & $0 \mathrm{~min}$ & $15 \mathrm{~min}$ & $30 \mathrm{~min}$ & $45 \mathrm{~min}$ & $60 \mathrm{~min}$ & $90 \mathrm{~min}$ & $120 \mathrm{~min}$ \\
\hline \multirow{3}{*}{$\begin{array}{l}\text { Glucose } \\
(n=44)\end{array}$} & $X \pm \mathrm{SD}$ & $86.5 \pm 7.4$ & $129.0 \pm 17.0$ & $146.0 \pm 17.3$ & $135.7 \pm 20.2$ & $121.3 \pm 23.9$ & $107.5 \pm 22.9$ & $92.0 \pm 15.0$ \\
\hline & $\mathrm{Me}$ & 88 & 128 & 147 & 131.5 & 119 & 105 & 93 \\
\hline & $\min -\max$ & $64-100$ & $96-168$ & $100-188$ & $105-181$ & $83-199$ & $64-180$ & $61-125$ \\
\hline \multirow{3}{*}{$\begin{array}{l}\text { Couscous } \\
(\mathrm{n}=8)\end{array}$} & $X \pm \mathrm{SD}$ & $87.0 \pm 5.8$ & $117.6 \pm 13.2$ & $126.6 \pm 8.5$ & $126.0 \pm 20.0$ & $120.0 \pm 15.5$ & $114.3 \pm 33.5$ & $99.1 \pm 23.1$ \\
\hline & $\mathrm{Me}$ & 88 & 116 & 127 & 122.5 & 117.5 & 106 & 92 \\
\hline & $\min -\max$ & $77-94$ & $96-133$ & $109-137$ & $94-157$ & $102-146$ & $88-194$ & $71-148$ \\
\hline \multirow{3}{*}{$\begin{array}{l}\text { Millet } \\
(\mathrm{n}=8)\end{array}$} & $X \pm \mathrm{SD}$ & $91.4 \pm 6.8$ & $115.6 \pm 11.6$ & $122.0 \pm 14.1$ & $111.4 \pm 11.1$ & $111.9 \pm 11.3$ & $92.5 \pm 11.7$ & $96.8 \pm 10.8$ \\
\hline & $\mathrm{Me}$ & 94 & 118 & 124 & 105 & 111 & 86 & 94.5 \\
\hline & $\min -\max$ & $81-100$ & $101-130$ & $104-147$ & $103-133$ & $96-127$ & $82-112$ & $85-114$ \\
\hline \multirow{3}{*}{$\begin{array}{l}\text { Spelt } \\
(\mathrm{n}=8)\end{array}$} & $X \pm \mathrm{SD}$ & $84.1 \pm 9.1$ & $121.4 \pm 8.0$ & $117.9 \pm 21.7$ & $109.6 \pm 26.0$ & $100.4 \pm 22.3$ & $101.1 \pm 15.3$ & $90.5 \pm 9.6$ \\
\hline & $\mathrm{Me}$ & 85 & 122.5 & 118.5 & 105 & 94 & 101 & 93 \\
\hline & $\min -\max$ & $71-101$ & $108-131$ & $90-154$ & $85-158$ & $81-148$ & $83-131$ & $77-101$ \\
\hline \multirow{3}{*}{$\begin{array}{l}\text { Bulgur } \\
(\mathrm{n}=8)\end{array}$} & $X \pm \mathrm{SD}$ & $86.6 \pm 9.1$ & $120.5 \pm 9.2$ & $115.8 \pm 21.5$ & $111.4 \pm 20.0$ & $130.9 \pm 10.7$ & $93.9 \pm 10.6$ & $95.9 \pm 13.4$ \\
\hline & $\mathrm{Me}$ & 85 & 121.5 & 118 & 108 & 102.5 & 93 & 97 \\
\hline & $\min -\max$ & $73-101$ & $102-130$ & $73-144$ & $80-139$ & $88-118$ & $83-109$ & $66-108$ \\
\hline \multirow{3}{*}{$\begin{array}{l}\text { Buckwheat, } \\
\text { roasted } \\
(\mathrm{n}=8)\end{array}$} & $X \pm \mathrm{SD}$ & $88.5 \pm 8.3$ & $112.6 \pm 13.2$ & $119.5 \pm 15.6$ & $102.9 \pm 14.4$ & $99.0 \pm 10.3$ & $92.0 \pm 16.8$ & $90.4 \pm 6.7$ \\
\hline & $\mathrm{Me}$ & 84.5 & 109 & 116 & 102 & 98 & 89 & 91.5 \\
\hline & min-max & 79-104 & $93-131$ & $98-145$ & $81-129$ & $79-114$ & $72-123$ & $78-98$ \\
\hline \multirow{3}{*}{$\begin{array}{l}\text { Barley, } \\
\text { hulled } \\
(n=8)\end{array}$} & $X \pm \mathrm{SD}$ & $85.6 \pm 3.2$ & $97.4 \pm 4.9$ & $101.9 \pm 8.7$ & $98.0 \pm 9.5$ & $95.0 \pm 9.0$ & $94.0 \pm 7.0$ & $87.9 \pm 5.8$ \\
\hline & $\mathrm{Me}$ & 85 & 95 & 105.5 & 100.5 & 96 & 93 & 87.5 \\
\hline & $\min -\max$ & $81-91$ & $92-105$ & $83-109$ & $82-111$ & $82-106$ & $87-109$ & $78-97$ \\
\hline
\end{tabular}

$X \pm \mathrm{SD}-$ mean \pm standard deviation; $\mathrm{Me}-$ median

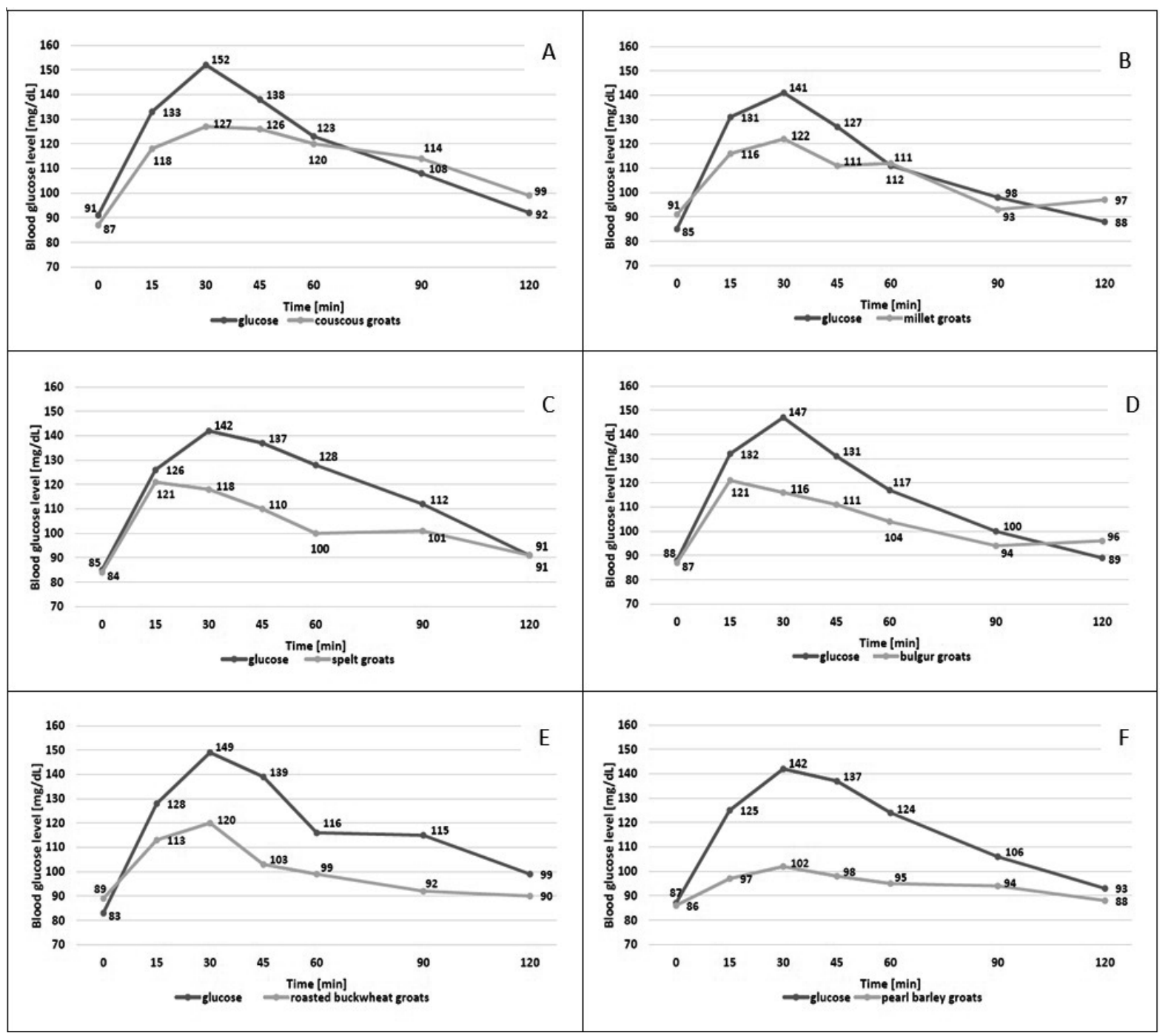

Figure 1. The blood glucose curves after the intake of glucose and tested groats: A - couscous, B - millet, $\mathrm{C}-$ spelt, $\mathrm{D}$ - bulgur, E - roasted buckwheat, F - pearl barley 
Table 4. Mean values $(X \pm \mathrm{SD})$ of glycemic index and glycemic load of the tested products

\begin{tabular}{|l|c|c|c|c|c|c|}
\hline \multirow{2}{*}{ Groats } & \multicolumn{3}{|c|}{ Glycemic index (\%) } & \multicolumn{3}{c|}{$\begin{array}{c}\text { Glycemic load (g) per 100g } \\
\text { of cooked product }\end{array}$} \\
\cline { 2 - 7 } & $X \pm \mathrm{SD}$ & Me & min-max & $X \pm \mathrm{SD}$ & Me & $\min -\max$ \\
\hline Couscous $(\mathrm{n}=8)$ & $99.0 \pm 36.0$ & 99.7 & $50.3-153.5$ & $24.7 \pm 9.0$ & 24.8 & $12.5-38.2$ \\
\hline Millet $(\mathrm{n}=8)$ & $56.2 \pm 20.6$ & 45.8 & $32.0-83.8$ & $12.6 \pm 4.6$ & 10.3 & $7.2-18.8$ \\
\hline Spelt $(\mathrm{n}=8)$ & $69.8 \pm 35.0$ & 61.0 & $34.2-142.1$ & $12.8 \pm 6.4$ & 11.2 & $6.3-26.1$ \\
\hline Bulgur $(\mathrm{n}=8)$ & $64.5 \pm 36.8$ & 56.9 & $25.4-138.9$ & $12.2 \pm 7.0$ & 10.8 & $4.8-26.3$ \\
\hline Buckwheat, roasted $(\mathrm{n}=8)$ & $34.7 \pm 8.2$ & 34.5 & $25.5-47.6$ & $8.1 \pm 1.9$ & 8.1 & $6.0-11.1$ \\
\hline Barley, hulled (n=8) & $31.3 \pm 13.4$ & 29.1 & $12.3-53.4$ & $8.0 \pm 3.4$ & 7.4 & $3.1-13.6$ \\
\hline
\end{tabular}

$X \pm \mathrm{SD}-$ mean \pm standard deviation; Me - median

The glycemic curve for couscous was very close to the glycemic curve for glucose. The glycemic curve for glucose varied the most in comparison to the glycemic curve for buckwheat and barley groats.

The values of glycemic index for each groats and the values of glycemic load (per $100 \mathrm{~g}$ of cooked product) are shown in Table 4. The lowest GI was calculated for buckwheat $(34.7 \pm 8.2 \%)$ and barley $(31.3 \pm 13.4 \%)$ groats. They also had the lowest GL amounted to $8.1 \pm 1.9$ and $8.0 \pm 3.4$, respectively. The GI for millet, spelt and bulgur groats amounted to $56.2 \pm 20.6 \%, 69.8 \pm 35.0 \%, 64.5 \pm 36.8 \%$, respectively, while for couscous amounted to $99.0 \pm 36.0 \%$.

\section{DISCUSSION}

The study herein was conducted to assess the glycemic index and glycemic load of the following groats available on the Polish food market: couscous, buckwheat (roasted) groats, millet groats, spelt groats, barley (hulled) groats and bulgur groats. Groats are food items usually associated with healthy diet as they are a source of fiber, vitamins and minerals. However among different types of groats there are some with high GI thus they cannot be recommended in everyday diet.

In the International Tables of Glycemic Index and Glycemic Load Values there are few GI values for barley ranged from $20 \%$ (Barley kernels, high-amylose (hull-less) boiled in water for $25 \mathrm{~min}$, reference food - bread) to 37\% (Barley, pot, boiled $20 \mathrm{~min}$, reference food - bread). The mean of eight studies given in the international tables is $28 \%$, what is similar to the results obtained in this study [1]. According to $\mathrm{FAO} /$ WHO report [12] the GI for pearled barley is $36 \%$, while for cracked barley $72 \%$. For buckwheat there is only one data in the international tables [1]. The GI for this groats is $45 \%$ (reference food - bread), however it is difficult to compare this value with the results observed in this study, because in the international tables buckwheat was more processed. It was hydrothermally treated, dehusked and boiled for 12 minutes. In the University of Sydney database [20] GI for buckwheat is $51 \%$. According to FAO/WHO report [12] the GI for buckwheat is $78 \%$. Both, barley and buckwheat groats, used in our study can be classified as a low GI food.

The GI for millet and bulgur groats amounted to $56.2 \pm 20.6 \%$ and $64.5 \pm 36.8 \%$, respectively. Based on the results from this study these groats can be classified as a medium GI food. GL for these products were very similar and amounted to $12.6 \pm 4.6$ and $12.2 \pm 7.0$. GI for millet porridge (reference food - glucose) in the international tables is higher that assessed in this study $(62 \%)$, but it is still a medium GI food [1]. According to $\mathrm{FAO} / \mathrm{WHO}$ report [12] millet has very high GL equal to $101 \%$. In The University of Sydney database [20] GI for millet boiled is $71 \%$ but for millet flour porridge $107 \%$. GI values for bulgur groats are not available in the International Tables of Glycemic Index and Glycemic Load Values [1], however are available in the University of Sydney database [20]. The GI for bulgur cracked wheat, boiled 20 minutes is $46 \%$ (time period of test 3 hours) so it is lower than assessed in this study. However FAO/WHO [12] data shows that GI for bulgur is $68 \%$, what is very similar to the results observed in this study. There is no data in the literature about GI for spelt groats. In this study it was assessed that the GI for spelt is $69.8 \pm 35.0 \%$ and the GL is $12.8 \pm 6.4$.

The GI for couscous assesses in this study was very high and amounted to $99.0 \pm 36.0 \%$. FAO/WHO [12] data shows that GI for couscous is $93 \%$, what is very similar to the results observed in this study. This value was significantly higher than those in international tables $(65 \%)$. In the University of Sydney database [20] GI for couscous ranged from 53 to $65 \%$ [1]. According to the results obtained in this study couscous can be classified as a high GI food. Couscous had also the highest GL, about 3 fold higher than barley or buckwheat groats. 
The individual values of GI were very different for one product. The greatest differences were observed for bulgur, spelt and couscous. To obtain more precise results the number of samples probably should be higher, however Mikolajczak et al. [16] had included about 20 volunteers to assess GI for one product and standard deviation was also very high. Moreover in the study conducted by Mikolajczak et al. [16] the values of GI were analyzed separately for men and women. For some products the values of GI were higher among men than women (oat cereals instant: $62.0 \pm 15.8 \%$ vs. $48.4 \pm 24.5 \%$, chocolate cereals: $51.5 \pm 19.4 \%$ vs. $46.5 \pm 24.7 \%$ ), but for another among women in comparison to men (cheerios multigrain cereals: $92.8 \pm 42.9 \%$ vs. $42.3 \pm 14.8 \%$, oat cereals: $48.6 \pm 28.3 \%$ vs. $36.5 \pm 16.1 \%)$. On the other hand, the value of GI assessed for muesli tropical was almost equal in the group of men and women [16]. Also in the study conducted by Bator et al. [4] the individual values of GI differed for one product. For example the minimum GI for Wasa crispbread with sesame was $11 \%$, while the highest $121 \%$ and the minimum GI for Wasa crispbread sport was $36 \%$, while the highest $160 \%$ [4].

The Central Statistical Office in Poland [7] assessed that the intake of grain products (excluding bread, flour and bakery products) in Poland in 2017 amounted only to $0.8 \mathrm{~kg}$ per month per capita. Within this amount 0.15 $\mathrm{kg}$ contained rice, $0.38 \mathrm{~kg}$ pasta and $0.15 \mathrm{~kg}$ breakfast cereals. There is no data about groats, however in regard to the consumption of other grains product, the intake of groats was lower or about $0.12 \mathrm{~kg}$ per month per capita. Groats products are very important in everyday diet and their consumption should be higher. They are source of carbohydrates, dietary fiber, minerals and B vitamins. Taking into account the nutritional value from the food label the content of dietary fiber in the analyzed groats ranged from $3.2 \mathrm{~g} / 100 \mathrm{~g}$ in millet to $9.6 \mathrm{~g} / 100 \mathrm{~g}$ in spelt. The content of minerals in these products is as follows: potassium from $166 \mathrm{mg}$ in couscous to $443 \mathrm{mg}$ in buckwheat, phosphorus from $170 \mathrm{mg}$ to $459 \mathrm{mg}$ and magnesium from $44 \mathrm{mg}$ to $218 \mathrm{mg}$, respectively. The content of zinc is more than $3 \mathrm{mg} / 100 \mathrm{~g}$ in millet, spelt and buckwheat, but lower than $1 \mathrm{mg} / 100 \mathrm{~g}$ in couscous and barley. The highest content of thiamine is in millet $(0.73 \mathrm{mg} / 100 \mathrm{~g})$, of niacin in spelt $(6.84 \mathrm{mg} / 100 \mathrm{~g})$, of vitamin $B_{6}$ in millet $(0.75 \mathrm{mg} / 100 \mathrm{~g})$. The lowest content of these vitamins is in barley $(0.14 \mathrm{mg} / 100 \mathrm{~g})$, buckwheat $(1.95 \mathrm{mg} / 100 \mathrm{~g})$ and couscous $(0.11 \mathrm{mg} / 100 \mathrm{~g})$, respectively [14, 21].

High dietary GI and/or GL in many studied was associated with higher risk of type 2 diabetes, CHD, stroke and cancer [3, 6, 11, 18, 19, 22]. Moreover Schwingshackl and Hoffmann [17] based on a metaanalysis found beneficial effects of long-term use of a low GI/GL diet with respect to fasting insulin and C-reactive protein what is also important in the primary prevention of non-communicable chronic disease, mainly associated with obesity. The low GI/GL of the diet may be achieved by the replacement of high GI/GL food by low GI/GL food and/or by reducing the intake of carbohydrates. More advisable is reduction of dietary GL through the intake of low GI food, not through the very restricted limitation in carbohydrate intake overall. McMillan-Price et al. [15] compared the effect of four diets with different amount and type of carbohydrates in weight loss and reduction of the cardiovascular risk. The first diet contained 55\% of energy from carbohydrates and GL $116 \mathrm{~g} ; 2^{\text {nd }}-55 \%$ energy from carbohydrates and GL $65 \mathrm{~g} ; 3^{\text {rd }} 25 \%$ energy from carbohydrates and GL 84 g; $4^{\text {th }} 25 \%$ energy from carbohydrates and GL $43 \mathrm{~g}$, respectively. Dietary GL was significantly associated with the glucose and insulin level in blood. Each diet caused weight loss, but the lowest effect was for the $1^{\text {st }}$ and the highest for the $2^{\text {nd }}$ diet. After 12 weeks of the study the $2^{\text {nd }}$ diet caused a reduction of total and LDL cholesterol level by 0.18 and $0.17 \mathrm{mmol} / 1$, while the $3^{\text {rd }}$ caused an increase level of these parameters by 0.24 and $0.26 \mathrm{mmol} / 1$, respectively. The authors also observed the highest reduction of leptin level in blood in the group on the $2^{\text {nd }} \operatorname{diet}[15]$.

Taking into account the results obtained in this study the most valuable among the tested groats in view of the prevention of non-communicable chronic diseases will be buckwheat and barley. These groats can be also chosen by people with diabetes, because they do not caused hyperglycemia. Bulgur and millet have medium GI, however they are rich in minerals and vitamin, so they can be chosen from time to time, however their consumption by people with diabetes should be limited. Couscous have the highest GI and the content of minerals and vitamin is rather small, so the intake of this groats should be limited in view of the prevention of chronic diseases, and even excluded by people with diabetes.

There is no Polish database with the values of GI for typical Polish food. The obtained results may be important for dietary recommendation in the prevention and treatment of non-communicable chronic diseases but also for healthy population who take care about healthy lifestyle and healthy nutrition. It should be obligatory recommend to include the value of GI on the food labels, what would help people in making an aware decisions.

\section{CONCLUSIONS}

The groats tested in this study can be classified as follows: barley and buckwheat as a low GI food, millet and bulgur as a medium GI food, spelt and couscous as a high GI food. Simultaneously, barley and buckwheat 
groats had the lowest, while couscous had the highest GL. Buckwheat and barley groats should be chosen the most often among these products, while the intake of couscous should be limited especially by people with diabetes.

\section{Acknowledgements}

This research was funded by the Wroclaw Medical University (Poland), Project No. ST.E110.16.062.

\section{Conflict of interest}

The authors declare that they have no conflict of interest.

\section{REFERENCES}

1. Atkinson F.S., Foster-Powell K., Brand-Miller J.C.: International Tables of Glycemic Index and Glycemic Load Values. Diabetes Care 2008; 31(12): 2281-2283.

2. Augustin L.S., Kendall C.W., Jenkins D.J., Willett W.C., Astrup A., Barclay A.W., Björck I., Brand-Miller J.C., Brighenti F., Buyken A.E., Ceriello A., La Vecchia C., Livesey G., Liu S., Riccardi G., Rizkalla S.W., Sievenpiper J.L., Trichopoulou A., Wolever T.M., BaerSinnott S., Poli A.: Glycemic index, glycemic load and glycemic response: An International Scientific Consensus Summit from the International Carbohydrate Quality Consortium (ICQC). Nutr Metab Cardiovasc Dis 2015; 25(9): 795-815.

3. Augustin L.S., Taborelli M., Montella M., Libra M., La Vecchia C., Tavani A., Crispo A., Grimaldi M., Facchini G., Jenkins D.J., Botti G., Serraino D., Polesel J.: Associations of dietary carbohydrates, glycaemic index and glycaemic load with risk of bladder cancer: a casecontrol study. Br J Nutr 2017; 118(9): 722-729.

4. Bator E., Mikołajczak J., Piotrowska E., FigurskaCiura D., Orzet D., Wyka J., Biernat J., Bronkowska M.: Wartości indeksów i ładunków glikemicznych wybranych rodzajów wafli zbożowych oraz pieczywa chrupkiego. Probl Hig Epidemiol 2014; 95(4): 941-947.

5. Brouns F., Bjorck I., Frayn K.N., Gibbs A.L., Lang V., Slama G., Wolever T.M.: Glycaemic index methodology. Nutr Res Rev 2005; 18(1): 145-171.

6. Burger K.N., Beulens J.W., Boer J.M., Spijkerman A.M., van $\operatorname{der} A$ D.L.: Dietary glycemic load and glycemic index and risk of coronary heart disease and stroke in Dutch men and women: The EPIC-MORGEN study. PLoS ONE 2011; 6(10): e25955. doi:10.1371/journal. pone.0025955.

7. Central Statistical Office in Poland. Household budget survey in 2017. Statistics Poland, Warsaw 2018.

8. Ciok J., Dzieniszewski J., Lang V.: Oznaczenie indeksu glikemicznego i insulinowego sześciu produktów pochodzenia zbożowego. Żyw Człow Metab 2004; 31(1): 63-77.

9. Dolna A., Ciok J., Szponar L.: Oznaczanie indeksu glikemicznego wybranych potraw typowych dla kuchni polskiej. Żyw Człow Metab 2006; 33(3): 199-211.
10. Dong J.Y., Zhang L., Zhang Y.H., Qin L.Q.: Dietary glycaemic index and glycaemic load in relation to the risk of type 2 diabetes: a meta-analysis of prospective cohort studies. Br J Nutr 2011; 106(11): 1649-1654.

11. Dong J.Y., Zhang Y.H., Wang P., Qin L.Q.: Metaanalysis of dietary glycemic load and glycemic index in relations to risk of coronary heart disease. Am J Cardiol 2012; 109(11): 1608-1613.

12. FAO/WHO. Agriculture and Consumer Protection Department. Carbohydrates in human nutrition: Report of a Joint FAO/WHO Expert Consultation, Rome, 14-18 April 1997. Rome: Food and Agriculture Organization, 1998. (FAO Food and Nutrition Paper No. 66.); http:// www.fao.org/docrep/W8079E/W8079E00.htm

13. Foster-Powell K., Holt A.H., Brand-Miller J.C.: International Table of Glycemic Index and Glycemic Load Values: 2002. Am J Clin Nutr 2002; 76(1): 5-56.

14. Kunachowicz H., Przygoda B., Nadolna I., Iwanow K.: Food Composition Tables. Warsaw, PZWL, 2017.

15. McMillan-Price J., Petocz P., Atkinson F., O'Neill K., Samman S., Steinbeck K., Caterson I., Brand-Miller $J$ : Comparison of 4 diets of varying glycemic load on weight loss and cardiovascular risk reduction in overweight and obese young adults. Arch Intern Med 2006; 166(14): 1466-1475.

16. Mikołajczak J., Bator E., Bronkowska M., Piotrowska E., Orzeł D., Wyka J., Biernat J.: Wartości indeksów i ładunków glikemicznych wybranych płatków zbożowych spożywanych z mlekiem. Rocz Panstw Zakl Hig 2012; 63(4): 433-440.

17. Schwingshackl L., Hoffmann G.: Long-term effects of low glycemic index/load vs. high glycemic index/load diets on parameters of obesity and obesity-associated risks: A systematic review and meta-analysis. Nutr Metab Cardiovasc Dis 2013; 23(8): 699-706.

18. Sieri S., Krogh V., Agnoli C., Ricceri F., Palli D., Masala G., Panico S., Mattiello A., Tumino R., Giurdanella M.C., Brighenti F., Scazzina F., Vineis P., Sacerdote C.: Dietary glycemic index and glycemic load and risk of colorectal cancer: results from the EPIC-Italy study. Int J Cancer 2015; 136(12): 2923-2931.

19. Sieri S., Pala V., Brighenti F., Agnoli C., Grioni S., Berrino F., Scazzina F., Palli D., Masala G., Vineis P., Sacerdote C., Tumino R., Giurdanella M.C., Mattiello A., Panico S., Krogh V.: High glycemic diet and breast cancer occurrence in the Italian EPIC cohort. Nutr Metab Cardiovasc Dis 2013; 23(7): 628-634.

20. The University of Sydney, Glycemic index database: https://www.glycemicindex.com/index.php(access: 11.12.2018)

21. USDA Food Composition Databases: https://ndb.nal. usda.gov/ndb/search/list (access: 12.12.2018)

22. Xu W.H., Xiang Y.B., Zhang X., Ruan Z., Cai H., Zheng W., Shu X.O.: Association of dietary glycemic index and glycemic load with endometrial cancer risk among Chinese women. Nutr Cancer 2015; 67(1): 89-97.

Received: 11.02 .2020

Accepted: 21.02.2020 